\title{
Effect of Herbal Galactogogue Supplementation on Production Performance of Lactating Kankrej Cows
}

\author{
V.K. Patel ${ }^{1}$, H.D. Chauhan ${ }^{1}$, M.M. Pawar ${ }^{2}$, A.K. Srivastava ${ }^{1 *}$ and K.B. Prajapati $^{1}$ \\ ${ }^{1}$ Department of Livestock Production and Management, ${ }^{2}$ Department of Animal Nutrition, \\ College of Veterinary Science and Animal Husbandry, Sardarkrushinagar Dantiwada \\ Agricultural University, Sardarkrushinagar - 385 506, Gujarat, India \\ *Corresponding author
}

\section{A B S T R A C T}

\section{Keywords}

Feed efficiency, Herbal galactogogue, Kankrej, Milk yield, Net return.

Article Info

Accepted:

17 October 2017

Available Online:

10 December 2017
The present study was undertaken to evaluate the efficacy of herbal galactogogue mixture containing Asparagous racemosous (Shatavari), Leptadenia reticulata (Jivanti) and Trigonella foenum-graecum (Fenugreek) on production performance of lactating Kankrej cows. Twenty four lactating Kankrej cows were divided equally into four treatment groups. The $\mathrm{T}_{1}$ group was fed with basal diet without herbal mixture supplementation (control); groups $\mathrm{T}_{2}, \mathrm{~T}_{3}$ and $\mathrm{T}_{4}$ were fed with basal diet $+30,60$ and $90 \mathrm{~g} / \mathrm{cow} /$ day herbal mixture supplementation, respectively. The dry matter intake was comparable among all the treatment groups. Average daily milk yield and $4 \%$ fat corrected milk yield were significantly $(\mathrm{P}<0.05)$ higher in herbal galactogogue supplemented groups as compared to the control group. No significant differences were observed in milk composition among the different treatments. The percentage daily return over control was $23.95,24.89$ and 19.25 in $T_{2}, T_{3}$ and $T_{4}$ groups. Supplementation of Shatavari, Jivanti and Fenugreek in equal proportion at the dose rate of $60 \mathrm{~g} / \mathrm{cow} /$ day resulted in significant increase in milk yield and daily return income in lactating Kankrej cows.

\section{Introduction}

Kankrej is one of the important Indigenous breeds of cattle in India and is found in SouthEast Rann of Kutch comprising of Mehsana, Kutch, Ahmedabad, Kheda, Sabarkantha and Banaskantha districts of Gujarat and Barmer and Jodhpur districts of Rajasthan. The Kankrej cattle are very highly priced as fast, powerful draft cattle. They are also fair producer of milk. Average milk yield of Kankrej cattle is around $1,738 \mathrm{~kg}$, average calving interval is around 450 days and fat content varies from 2.9 to 4.2 percent (NBAGR, 2017). Whereas, average standard (305 days) lactation yield was 2627 liters with average calving interval of 447 days has been achieved in in Kankrej cows maintained at Livestock Research Station, Sardarkrushinagar Dantiwada Agricultural University, Gujarat (Anonymous, 2017). The optimum milk production is the basic requirement of dairy economics and the milk yield can be increased by the use of certain galactogogue herbs in cattle. Galactogogues are the substances which are believed to assist in the initiation, maintenance, or augmentation of maternal milk production. They increase prolactin secretion by antagonizing dopamine receptors (Gabay, 
2002), stimulate the activity of mammary alveolar tissue and thereby regulate milk yield (Ravikumar and Bhagwat, 2008).

Shatavari (Asparagous racemosous) is one of the most commonly used herbs in traditional medicine due to presence of steroidal saponins and sapogenins (Krishana et al., 2005). It acts as galactogogue and enhances the blood prolactin level and stimulates the cellular division of mammary gland (Pandey et al., 2005; Kumar et al., 2014). Jivanti (Leptadenia reticulata) is considered to be a tonic drug and is used to vitalize, nourish and rejuvenate the body. It has potent lactogenic, anabolic and galactogogue effect (Ravishankar and Shukla, 2007). Fenugreek (Trigonella foenum-graecum) has been used as such for centuries as a purpose of galactogogue (Swafford and Berens, 2000). Positive effects of these galactogogue herbs on milk production in ruminants have been reported earlier by Patel et al., (2013), Balgees et al., (2013) and Degirmencioglu et al., (2016). The objective of the present study was to investigate the effects of galactogogue mixture of Shatavari, Jivanti and Fenugreek on milk production and feeding economics of lactating Kankrej cows.

\section{Materials and Methods}

The present study was conducted at Livestock Research Station, SDAU, Gujarat which is located in semi -arid region of Banaskantha District of North Gujarat having latitude of $24.35^{\circ}$ North and longitude of $72.59^{\circ}$ East and at an elevation of 189 meters above the mean sea level. Twenty four lactating Kankrej cows were categorized into four treatment groups having six cows in each on the basis of parity, milk yield and body weights. The $\mathrm{T}_{1}$ group was fed with basal diet without herbal mixture supplementation (control) and groups $\mathrm{T}_{2}, \mathrm{~T}_{3}$ and $\mathrm{T}_{4}$ were fed basal diet + herbal mixture (Shatavari, Jivanti and Fenugreek at $1: 1: 1$ ratio) supplementation at the rate of 30,60 and $90 \mathrm{~g} / \mathrm{cow} /$ day, respectively. All the animals were fed balanced ration to fulfill the nutrient requirement as per ICAR (2013) feeding standard for a period of 60 days. The feeds and fodders used in the experiment were green maize, jowar hay, cotton seed cake and concentrate mixture. The concentrate mixture was composed of crushed maize grain, $20 \%$; de-oiled rice bran, 35\%; rice polish, $10 \%$; molasses, $10 \%$, rape seed cake, $15 \%$, guar bhardo, $7 \%$, mineral mixture, $2 \%$ and common salt, $1 \%$. The chemical composition of feeds and fodders were analyzed as per AOAC (1995) procedures.

All the cows were reared under standard management practices with free access to fresh and clean drinking water. All cows were milked twice a day (morning 4:00 a.m. and evening 4:00 p.m.) and individual milk yield of each cow was recorded daily during the experimental period of 60 days by using electronic weighing balance. For analysis of milk constituents, milk samples were collected at weekly interval. Milk fat, solid not fat (SNF), protein and lactose were determined by using EKOMILK Ultra Pro Milk Analyzer. Feed efficiency in terms of dry matter intake $\mathrm{kg} / \mathrm{kg}$ of milk yield in experimental lactating Kankrej cows was determined. Economics of feeding was calculated by considering expenditure on feeds and herbal mixture supplementation and return from the sale of milk.

\section{Statistical analysis}

The data obtained from the experiment were analysed statistically as per the procedures of Complete Randomized Design (Snedecor and Cochran, 1994). Treatment mean comparison was made by using Duncan's New Multiple Range Test (DNMRT) to verify significance difference among treatment mean values. The differences among treatments were declared significant at $\mathrm{p}<0.05$. 


\section{Results and Discussion}

The chemical composition of feeds and fodders fed to lactating cows is given in Table 1. The crude protein content in concentrate mixture, cotton seed cake, green maize and jowar hay was 18.59, 22.44, 5.37 and 4.81\%, respectively. Feed intake, milk yield and milk composition in lactating Kankrej cows fed herbal supplement are represented in Table 2. The dry matter intake in $\mathrm{T}_{1}, \mathrm{~T}_{2}, \mathrm{~T}_{3}$ and $\mathrm{T}_{4}$ groups was 9.25, 10.34, 10.21 and $10.55 \mathrm{~kg} / \mathrm{d}$, respectively, which was comparable among all the treatment groups. The similar feed intake observed in this study indicates that herbal supplementation did not have any adverse effect on palatability. The average milk yield was 8.78, 10.49, 10.67 and 10.55 $\mathrm{kg} / \mathrm{d}$ in groups $\mathrm{T}_{1}, \mathrm{~T}_{2}, \mathrm{~T}_{3}$ and $\mathrm{T}_{4}$, respectively.

The results indicated that supplementation of galactogogue mixture of herbs significantly increased milk yield as compared to control group. Also, 4\% fat corrected milk yield $(\mathrm{kg} / \mathrm{d})$ was significantly higher $(\mathrm{P}<0.05)$ in groups $\mathrm{T}_{2}$ (11.78), $\mathrm{T}_{3}$ (11.97) and $\mathrm{T}_{4}(11.75)$ than the group $T_{1}$ (9.90). The higher milk yield in herbal supplemented groups may be due to estrogenic effect of galactogogue herbs on mammary glands which stimulates alveolar secretory epithelial cell division and proliferation which helps in sustenance of increased milk production. Moreover, these herbs might have helped in optimizing the ruminal fermentation that ultimately increased the nutrient availability for milk production (Bhatt et al., 2009). Dadkhah and Yeganehzad (2011) also reported that supplementation of galactogogue herbal mixture in dairy cows had higher levels of hormone prolactin and insulin, which lead to increase milk production. Similar to present findings other workers (Patel et al., 2013; Sukanya et al., 2014; Galbat et al., 2014; Degirmencioglu et al., 2016) reported that dietary supplementation of herbal galactogogue in dairy animals significantly increased milk yield. No significant differences were observed in percentages of milk fat, SNF, protein, lactose and total solids among the different treatment groups. In agreement with our result, Tanwar et al., (2008), Baig and Bhagwat (2009) and Patel et al., (2013) who found that there was no significant effect on milk composition in dairy animals fed herbal supplementation.

The total feed cost, net return over feed cost and percentage daily return over control are given in Table 3. The total feed cost (Rs./cow/day) was 127.00, 135.34, 138.50 and 147.59; while net return over feed cost was $136.40,179.36,181.60$ and 168.91 in $\mathrm{T}_{1}$, $\mathrm{T}_{2}, \mathrm{~T}_{3}$ and $\mathrm{T}_{4}$ groups, respectively. The percentage daily return over control was $23.95\left(\mathrm{~T}_{2}\right), 24.89\left(\mathrm{~T}_{3}\right)$ and $19.25\left(\mathrm{~T}_{4}\right)$ in herbal galactogogue supplemental groups.

Table.1 Chemical composition (\% DM basis) of feeds and fodders

\begin{tabular}{lcccc}
\hline Composition $(\boldsymbol{\%})$ & Concentrate mixture & Cotton seed cake & Green Maize & Jowar hay \\
\hline Crude protein & 18.59 & 22.44 & 5.37 & 4.81 \\
Crude fibre & 8.58 & 10.43 & 32.53 & 39.35 \\
Ether extract & 3.43 & 8.33 & 1.42 & 1.05 \\
Ash & 12.2 & 7.37 & 9.57 & 8.01 \\
NFE & 57.2 & 51.43 & 48.89 & 53.22 \\
Calcium & 1.19 & 0.16 & 0.49 & 0.44 \\
Phosphorus & 0.96 & 1.07 & 0.25 & 0.06 \\
\hline
\end{tabular}


Table.2 Feed intake, milk yield and milk composition in lactating Kankrej cows fed herbal supplement $(\mathrm{n}=24)$

\begin{tabular}{|c|c|c|c|c|c|}
\hline \multirow{2}{*}{ Parameters } & \multicolumn{4}{|c|}{ Treatments } & \multirow{2}{*}{ SEM } \\
\hline & $\mathbf{T}_{1}$ & $\mathbf{T}_{2}$ & $\mathbf{T}_{\mathbf{3}}$ & $\mathbf{T}_{4}$ & \\
\hline Body weight (kg) & 458.33 & 441.67 & 452.17 & 445.67 & 3.664 \\
\hline DM intake $(\mathrm{kg} / \mathrm{d})$ & 10.06 & 10.34 & 10.21 & 10.55 & 0.104 \\
\hline DM intake (\% BW) & 2.19 & 2.34 & 2.26 & 2.37 & 0.041 \\
\hline Initial Milk yield $(\mathrm{kg} / \mathrm{d})$ & 7.09 & 7.32 & 7.17 & 7.23 & 0.049 \\
\hline Average Milk yield (kg/d) & $8.78^{\mathrm{a}}$ & $10.49^{\mathrm{b}}$ & $10.67^{\mathrm{b}}$ & $10.55^{\mathrm{b}}$ & 0.449 \\
\hline 4\% FCM yield $(\mathrm{kg} / \mathrm{d})$ & $9.90^{\mathrm{a}}$ & $11.78^{\mathrm{b}}$ & $11.97^{\mathrm{b}}$ & $11.75^{\mathrm{b}}$ & 0.486 \\
\hline Feed efficiency & 1.15 & 0.99 & 0.96 & 1.00 & 0.043 \\
\hline \multicolumn{6}{|l|}{ Milk composition (\%) } \\
\hline Milk fat & 4.86 & 4.82 & 4.80 & 4.75 & 0.023 \\
\hline Milk SNF & 9.42 & 9.60 & 9.66 & 9.69 & 0.060 \\
\hline Milk protein & 3.96 & 4.02 & 4.11 & 4.13 & 0.040 \\
\hline Milk lactose & 4.74 & 4.86 & 4.93 & 4.90 & 0.042 \\
\hline Milk total solids & 14.28 & 14.41 & 14.46 & 14.43 & 0.040 \\
\hline
\end{tabular}

Table.3 Economics of feeding herbal supplement to lactating Kankrej cows ( $n=24)$

\begin{tabular}{lcccc}
\hline \multirow{2}{*}{ Parameters } & \multicolumn{4}{c}{ Treatments } \\
\cline { 2 - 5 } & $\mathbf{T}_{\mathbf{1}}$ & $\mathbf{T}_{\mathbf{2}}$ & $\mathbf{T}_{\mathbf{3}}$ & $\mathbf{T}_{\mathbf{4}}$ \\
\hline Feed cost (Rs./cow/day) & 127.00 & 130.54 & 128.90 & 133.19 \\
Supplement cost (Rs./cow/day) & 0.00 & 4.80 & 9.60 & 14.40 \\
Total feed cost (Rs./cow/day) & 127.00 & 135.34 & 138.50 & 147.59 \\
Average milk yield (kg/day) & 8.78 & 10.49 & 10.67 & 10.55 \\
Receipt from sale of milk @ Rs.30/kg & 263.4 & 314.7 & 320.1 & 316.5 \\
(Rs./cow/day) & 136.40 & 179.36 & 181.60 & 168.91 \\
Net return over feed cost (Rs./cow/d) & - & 23.95 & 24.89 & 19.25 \\
\% daily return over control & & & & \\
\hline
\end{tabular}

The total feed cost, net return over feed cost and percentage daily return over control are given in Table 3. The total feed cost (Rs./cow/day) was 127.00, 135.34, 138.50 and 147.59; while net return over feed cost was $136.40,179.36,181.60$ and 168.91 in $\mathrm{T}_{1}$, $\mathrm{T}_{2}, \mathrm{~T}_{3}$ and $\mathrm{T}_{4}$ groups, respectively. The percentage daily return over control was $23.95\left(\mathrm{~T}_{2}\right), 24.89\left(\mathrm{~T}_{3}\right)$ and $19.25\left(\mathrm{~T}_{4}\right)$ in herbal galactogogue supplemental groups. The result of present study concurred with the findings of Tanwar et al., (2008), Patel et al., (2013), Kumar et al., (2014) and Sukanya et al.,
(2014) who reported herbal galactogogue supplementation reduced the cost per $\mathrm{kg}$ milk production and increased daily return in dairy animals.

Supplementation herbal galactogogue mixture of Shatavari (Asparagous racemosous), Jivanti (Leptadenia reticulata) and Fenugreek (Trigonella foenum-graecum) in equal proportion at the dose rate of $60 \mathrm{~g} / \mathrm{cow} /$ day resulted in significant increase in milk yield and daily return income in lactating Kankrej cows. 


\section{Acknowledgements}

The authors are grateful to the Director of Research, Sardarkrushinagar Dantiwada Agricultural University, Sardarkrushinagar, Gujarat for providing the necessary facilities to carry out this research work.

\section{References}

Anonymous. 2017. Annual Progress Report (Jan. to Dec., 2016) Research Sub Committee on Animal Production (Feb 14th, 2017), 13th Meeting held at SDAU, Sardarkrushinagar, Gujarat.

AOAC. 1995. Official Methods of Analysis. $16^{\text {th }}$ edn., Association of Official Analytical Chemists, Washington, D.C. USA.

Baig, M.I. and Bhagwat, V.G. 2009. Study of the efficacy of Galactin Vet Bolus on milk yield in dairy cows. Veterinary World, 2(4): 140-142.

Balgees, A., Atta Elmnan Nuha, M., Jame, S.A., Rahmatalla, E.O., Amasiab, A. and Mahala, G. 2013. Effect of fenugreek (Trigonella foenum-graecum) seeds supplementation on feed intake, some metabolic hormones profile, milk yield and composition of Nubian goats. Research Journal of Animal Science, 7: 1-5.

Bhatt, N., Singh, M. and Ali, A. 2009. Effect of feeding herbal preparations on milk yield and rumen parameters in lactating crossbred cows. International Journal of Agricultural Biolology, 11(6): 721726.

Dadkhah, M.A. and Yeganehzad, M. 2011. The effects of extracts of plants (Medicago sativa, Trigonella foenum and Carum carvi) on milk production in dairy cows. Advances in Environmental Biology, 5(10): 3129-3134.

Degirmencioglu, T., Unal, H., Ozbilgin, S. and Kuraloglu, H. 2016. Effect of ground fenugreek seeds (Trigonella foenum-graecum) on feed consumption and milk performance in Anatolian water buffaloes. Archives Animal Breeding, 59: 345-349.

Gabay, M.P. 2002. Galactogogues: Medications that induce lactation. Journal of Human Lactation, 18(3): 274-279.

Galbat, S.A., El-Shemy, A., Madpoli, A.M., Omayma, M.A.L. Maghraby and Eman I. El-Mossalam. 2014. Effects of some medicinal plants mixture on milk performance and blood components of Egyptian dairy goats. Middle East Journal of Applied Sciences, 4(4): 942948.

ICAR. 2013. Nutrient Requirements of Cattle and Buffalo. Indian Council of Agricultural Research, New Delhi, India.

Krishna, L., Swarup, D. and Patra, R.C. 2005. An overview of prospects of ethanoveterinary medicine in India. The Indian Journal of Animal Science, 75(12): 1481-1489.

Kumar, S., Mehla, R.K. and Mahendra Singh. 2014. Effect of Shatavari (Asparagus racemosus) on milk production and immune-modulation in Karan Fries crossbred cows. Indian Journal of Traditional Knowledge, 13(2): 404-408.

NBAGR. 2017. National Bureau of Animal Genetic Resources. Available at http://14.139.252.116/agris/bridDescript ion.aspx accessed on $15^{\text {th }}$ February 2017.

Pandey, S.K., Sahay, A., Pandey, R.S. and Tripathi, Y.B. 2005. Effect of Asparagus racemosus rhizome (Shatavari) on mammary gland and genital organs of pregnant rat. Phytother Research, 19(8): 721-724.

Patel, M.D., Tyagi, K.K., Sorathiya, L.M. and Fulsoundar, A.B. 2013. Effect of polyherbal galactogogue 
supplementation on milk yield and quality as well as general health of Surti buffaloes of south Gujarat. Veterinary World, 6(4): 214-218.

Ravikumar, B.R. and Bhagwat, V.G. 2008. Study of the influence of Galactin Vet Bolus on milk yield in lactating dairy cows. Livestock Line, p. 5-7.

Ravishankar, B. and Shukla, V.J. 2007. Indian systems of medicine: A brief profile. African Journal of Traditional, Complementary and Alternative medicines, 4(3): 319-337.

Snedecor, G.W. and Cochran, W.G. 1994. Statistical Methods. $8^{\text {th }}$ edition. Oxford and IBH Publishing Co., Calcutta, India.
Sukanya, T.S., Rudraswamy, M.S. and Bharathkumar, T.P. 2014. Performance of Shatavari based herbal galactogogueMilkplus supplementation to crossbred cattle of Malnad region. International Journal of Science and Nature, 5(2): 362-363.

Swafford, S. and Berens, P. 2000. Effect of fenugreek on breast milk volume. $A B M$ News and Views, 6(3): 17-26.

Tanwar, P.S., Rathore, S.S. and Yogendra Kumar. 2008. Effect of Shatavari (Asparagus recemosus) on milk production in dairy animals. Indian journal of Animal Research, 42(3): 232233.

\section{How to cite this article:}

Patel, V.K., H.D. Chauhan, M.M. Pawar, A.K. Srivastava and Prajapati, K.B. 2017. Effect of Herbal Galactogogue Supplementation on Production Performance of Lactating Kankrej Cows. Int.J.Curr.Microbiol.App.Sci. 6(12): 2093-2098. doi: https://doi.org/10.20546/ijcmas.2017.612.239 